Науковий вісник НлТУ України Scientific Bulletin of UNFU

https://nv.nltu.edu.ua

https://doi.org/10.15421/40290608

Article received $13.06 .2019 \mathrm{p}$.

Article accepted 27.06.2019 p.

Удк 630.90

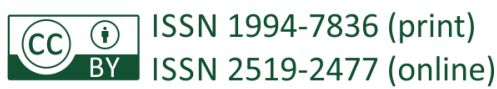

$@ \bowtie$ Correspondence author

S. S. Kovalevskyi

kovalevskyis.s@nubip.edu.ua

С. С. Ковалевський

Національний університет біоресурсів і природокористування України, м. Київ, Україна

\title{
ВИЯВЛЕННЯ ОСЕРЕДКІВ ДОБУВАННЯ БУРШТИНОВИХ КОПАЛИН НА ТЕРИТОРІЇ ЛІСОВИХ МАСИВІВ УКРАЇНИ
}

\begin{abstract}
Проаналізовано стан використання технологій дистанційного зондування землі (Д33) в лісових масивах України, де ведеться видобуток корисних копалин, на прикладі бурштину. Досліджено проблему незаконного видобутку бурштину здійснено аналіз обсягів шкоди, що завдається лісам у процесі такої діяльності з використанням авіаційної розвідки та супутникових знімків різної серії. Акцентовано увагу на масштаби антропогенного тиску на території лісових масивів України внаслідок видобування бурштину. Висвітлено здобутки вітчизняних установ супутникового дослідження порушених земель та розглянуто проблеми і перспективи застосування супутникових даних для вирішення завдань, пов'язаних 3 нелегальним видобутком бурштину. Проаналізовано можливості ідентифікації місць видобутку бурштину на територіях лісогосподарських підприємств за знімками Landsat, WorldView i Sentinel. Висока інформативність спостережень зі штучних супутників Землі дає змогу швидко й об'єктивно оцінювати ділянки, порушені видобутком бурштину та оцінити втрати лісових ресурсів, а також дослідити зміни, які відбулися у лісових насадженнях, виявлення нових місць видобутку для подальшого контролю їх правомірності. Цей метод виявлення осередків незаконного видобутку корисних копалин дає змогу своєчасно вживати заходів щодо раціонального використання лісових ресурсів і запобігати збиткам, заподіяним неконтрольованим захопленням лісових масивів з подальшим видобутком бурштинових копалин.
\end{abstract}

Ключові слова: видобуток бурштину; порушені землі; багатозональні супутникові знімки; лісові масиви; індексні та композитні зображення.

Вступ. Добування природних ресурсів на території України є основною складовою частиною соціальноекономічного становлення населення (рівень доходу населення, рівень зайнятості). Відповідно до цього в місцях видобування бурштину, а це природокористування в областях Поліського економічного району (Волинська, Житомирська, Рівненська області), є помітний негативний потенціал розвитку економіки та великий вплив на виснажливе користування лісовими ландшафтами. Наразі питання оптимальної взаємодії людини та навколишнього природного середовища гостро постають перед світовою спільнотою. На жаль, проблеми раціонального використання природних ресурсів не виносять на перший план, але вони характеризуються величезними масштабами змін ландшафтів. Особливо такі зміни відчутні у місцях видобування корисних копалин. Самовільний видобуток бурштину призводить до спаду економіки у країні та знищення природи через зміни рельєфу, винищення природних ландшафтів, погіршення стану грунтів, зміни у режимі поверхневих і грунтових вод і як наслідок - до тотального винищення лісових масивів.

Результати дослідження. На важливість та негайне вирішення цієї проблеми наголошувало багато вчених і посадових осіб, зокрема: О. Ю. Дрозд, С. М. Наумов, О. М. Вітенко, В. О. Баранова, І. І. Горин, В. В. Кривен- ко та багато інших (Baranova, 2015).

Загалом глобальний ринок бурштину-сирцю оцінюється Міжнародною асоціацією бурштину (англ. International Amber Association, IAA) у 1,2 млрд євро, а його щорічний видобуток становить від 500 до 800 т. Майже $80 \%$ від усього обсягу світу видобувається в Україні й у країнах Балтії, з них 30-40 \% припадає на нашу країну. Але на превеликий жаль, за офіційними даними, українські підприємства щорічно видобувають тільки близько 4 т, що становить не більше $5 \%$ від реального обсягу видобування бурштину в Україні, все решта видобувається "нелегальними" копачами i не контролюється державними органами, що завдає разючого удару економіці країни та збереженню природи.

Як вже було зазначено, основне місце залягання бурштинових копалин зосереджено у трьох областях Поліського регіону України: Волинській, Рівненській та Житомирській. За інформацією Волинської державної екологічної інспекції станом на 01.07.2015 р., загальна площа знищених лісів на Волині становила 9,06 га, Житомирського обласного управління лісового і мисливського господарства станом на 01.07.2015 р., загальна площа земель лісогосподарського призначення, на якій незаконно видобували бурштин, становила 572,80 га, 3 них пошкоджено - 178,25 га. У Житомирській обл. від нецивілізованого видобутку бурштину виявлено 220 га

Інформація про авторів:

Ковалевський Сергій Сергійович, канд. с.-г. наук, ст. викладач, кафедра таксації лісу та лісового менеджменту.

Email: kovalevskyis.s@nubip.edu.ua; https://orcid.org/0000-0002-6498-7794

Цитування за ДСту: Ковалевський С. С. Виявлення осередків добування бурштинових копалин на території лісових масивів України. Науковий вісник НЛТУ України. 2019, т. 29, № 6. С. 40-44.

Citation APA: Kovalevskyi, S. S. (2019). Detection of circuit focus of amber minerals on the territory of forests of Ukraine. Scientific Bulletin of UNFU, 29(6), 40-44. https://doi.org/10.15421/40290608 
пошкодженої землі, у Волинській обл. - 4 га, у Рівненській - 169 га пошкоджених земель, але наведені дані не $є$ постійними, оскільки мають залежність змінюватись у бік збільшення щодня. Відповідно до цього виникає проблема постійного моніторингу місць незаконного видобутку бурштину, визначення площ розроблених місць, а також оцінка завданої шкоди економіці та природному середовищу. Значна кількість ділянок, де ведеться незаконний видобуток бурштинових копалин, розташована у віддалених від проїзної частини та населених пунктів, важкодоступних закритих лісами територіях. Окрім цього, такі території зазвичай охороняють озброєні особи з невідомим підпорядкуванням, які безпосередньо перешкоджають доступу до порушених земель для проведення досліджень польовим методом. На сьогодні перспективним способом оцінити порушення $\epsilon$ використання безпілотних аерознімальних апаратів та застосування матеріалів космічних знімань.

Використання авіаційної розвідки Державними прикордонними службами показала високу активність нелегальних копачів у Житомирській і Рівненській областях. Зокрема, такі місця виявлено в Олевському р-ні Житомирської обл. та Рокитнівському, Зарічненському, Володимирецькому, Дубровицькому р-нах Рівненської обл. Авіарозвідкою було зафіксовано не тільки велику кількість копачів, автомобільної техніки, мотопомп та інших технічних засобів, а й встановлено незаконні вирубки лісу і підпільні склади контрабандних товарів у прикордонних областях. Незаконними рубками лісу були охоплені Володимир-Волинський p-н Волинської обл., Вовчанський р-н Харківської обл., Сокальський, Яворівський, Жидачівський, Стрийський р-ни Львівської обл., Краснопільський р-н Сумської обл., Сновський та Семенівський р-ни Чернігівської обл. Також 3 допомогою аерознімання в лісах виявлено незаконно обладнані місця для виготовлення деревного вугілля у промислових масштабах, що теж заподіює екологічний відбиток, оскільки нелегали не використовують обладнання, яке зменшує кількість шкідливих викидів (оксиди натрію і сірки, смола) в повітря, з огляду на його високу ціну. А ще у Львівській, Волинській, Тернопільській, Чернівецькій, Івано-Франківській, Рівненській та Вінницькій областях виявлено навіть злітно-посадкові смуги для невеликих літаків, які швидше за все використовують контрабандисти для переміщення вантажів через кордон.

Перспективним та досить точним методом проведення картографування та виявлення площ, порушених внаслідок видобутку бурштину, є використання БПЛА (безпілотних літальних апаратів). Однак застосування методу авіаційної розвідки та БПЛА є обмеженим, оскільки потребує істотних затрат часу, палива та є ризик втрати літальних апаратів від незаконних дій злочинців.

Отже, недостатнє вирішення проблеми моніторингу порушених земель внаслідок видобутку корисних копалин (бурштину) за допомогою наземних методів та 3 використанням аерометодів, не може повною мірою забезпечити потрібний обсяг інформації через швидке поширення і масштаби територій. Для вирішення цієі проблеми пропонують застосовувати матеріали багатозональних космічних знімків, що дає змогу з високою достовірністю визначати і локалізовувати місця незаконного видобутку та реально оцінювати масштаби екологічного лиха.
Для вирішення цієї проблеми пропонують методику застосування матеріалів багатозональних космічних зйомок, яка дає змогу з високою достовірністю визначити і локалізувати місця незаконного видобутку та реально оцінити масштаби екологічного лиха. Оптимальними вихідними матеріалами для виявлення територій, на яких ведеться незаконний видобуток бурштину, $\epsilon$ зображення, отримані супутниками серії Landsat, на регіональному рівні та WorldView-2, WorldView-3 на детальнішому рівні. Головним індикатором місць для полегшеного виявлення нелегального видобутку бурштину на космічних зображеннях $\epsilon$ наявність ділянок чергування відкритих відвалів піску і ям-копанок, що мають характерний спектральний образ, дрібно-комірчасту текстуру зображення та температурний контраст 3 навколишньою рослинністю. Методика виявлення i картографування ділянок нелегального видобутку полягає в такому:

- проводять послідовний аналіз багатоспектральних космічних даних на основі класифікацій за спектральними ознаками;

- оцінюють температурний приріст земної поверхні на локальних ділянках (за даними Landsat 8/TIRS);

- для достовірності класифікації порушених територій виконують наземні вибіркові спектрометричні дослідження поверхні відвалів у польових умовах, що дає змогу сформувати повний спектральний образ пошукового об'єкта та ідентифікувати його на космічному зображенні.

Детально цю методику оброблення космічних даних розглянуто у роботі Фліпович В. С., Крилова Г. Б., Лубського M. C. (Filipovych, Krylova, Lubskyi, 2015). За даними, отриманими під час оброблення супутникових зображень у видимому та ІЧ-діапазонах, на дослідних територіях за останні кілька років можливо простежити чітку тенденцію до заміщення лісової та чагарникової рослинності піщаними відкладами 3 характерною техногенною структурою поверхні, що свідчить про інтенсифікацію незаконного видобутку бурштину (рис. 1).
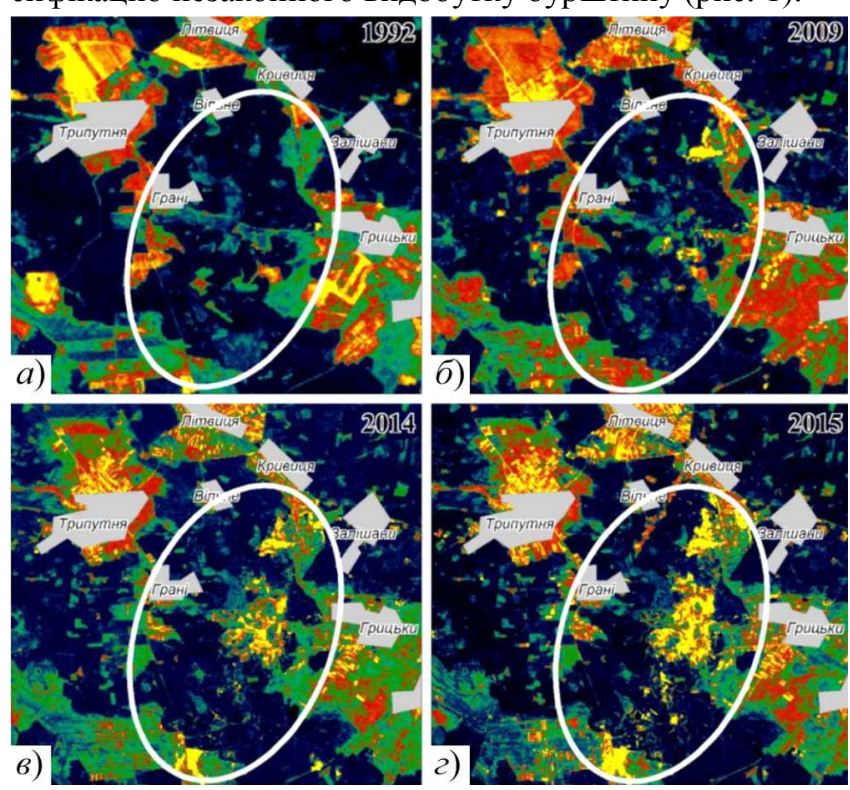

Рис. 1. Моніторинг територій нелегального видобутку бурштину на регіональному рівні

На рис. 1 зображено ділянку земної поверхні, на якій проводився видобуток бурштину, на прикладі Рівненської обл., Дубровицького р-ну, білим овалом окреслено ділянку 3 незаконним видобутком упродовж 1992-2015 pp. 
За даними спеціалістів державного управління "Науковий центр аерокосмічних досліджень Землі ІГН НАН України" (Filipovych, 2015), вартість оброблення космічних знімків становить від 2 до 40 дол. за км² (ціни наведено згідно 3 даними 2015 р.). Вартість може змінюватись залежно від масштабу, детальності і просторової розрізненості вихідних даних. Отже, ціна оброблення космічних даних значно нижча від тих втрат, яких зазнає держава від нелегального видобутку бурштину. Запропонована технологія виявлення порушених ділянок має універсальний характер і може використовуватися під час моніторингу дотримання природоохоронного законодавства на територіях відкритого видобутку інших корисних копалин, зокрема розсипних родовищ ільменіту, видобутку будівельної сировини тощо. Треба зазначити, що запропонований підхід до контролю у моніторинговому режимі місць нелегального видобутку бурштину і оперативна оцінка завданих державі збитків працює на основі ГІС-систем у напівавтоматичному режимі і не потребує значних об'ємів та не завжди безпечних польових досліджень. Мінімальний період отримання новітніх космічних даних для регіонального рівня (супутники серії Landsat, США)16 діб, локального рівня - доба (супутники серій WorldView, США, або Pleiades, Франція).

Наведена методика аналізу космічних даних дає змогу оперативно і з високою ймовірністю виявляти подібні ділянки, як для застосування запобіжних дій, так і для оцінки економічних та екологічних збитків, завданих природному середовищу (Filipovych, 2015).

Для кількісної оцінки наслідків незаконного видобутку бурштину можна запропонувати технологію оброблення знімків із супутників Landsat-7 (знімальний прилад ETM) i Landsat-8 (знімальний прилад OLI). Ця методика включає в себе такі основні етапи:

- зниження розмірності даних за допомогою методу головних компонент (англ. Principal Component Analysis - PCA);

- створення різницевого зображення для перших головних компонент двох різночасових знімків заданої території;

- подальша порогова бінаризація різницевого зображення;

- морфологічна фільтрація бінарного зображення;

- векторизація та розрахунок геометричних характеристик.

Виконавши обробку багатоспектральних знімків середнього просторового розрізнення із супутника Landsat-7 і Landsat-8, встановлено, що тільки на аналізованих супутникових знімках площа ділянок, що постраждали від незаконного видобутку бурштину, становила понад 500 га. На відміну від відомих методів виявлення зміни територій за різночасними супутниковими знімками Landsat, які базуються на даних панхроматичних каналів і індексних зображень, що використовують тільки дані двох спектральних каналів, запропонована методика дає змогу точніше виявляти постраждалі ділянки завдяки аналізу всіх спектральних каналів із застосуванням перетворення головних компонент (РСА) (Sakti \& Tsuyuki, 2015; Hnatushenko et al., 2016; Zhang et al., 2015). Окрім цього, запропонована технологія дає змогу аналізувати часові зміни на постраждалих ділянках для тривалих періодів спостереження, використовуючи створені векторні шари $з$ атрибутивною інформацією.

Розроблена методика може бути реалізована у вигляді веб-служби регулярного космічного моніторингу, що забезпечує отримання об'єктивної та достовірної ін- формації щодо масштабів і тяжкості наслідків незаконного видобутку бурштину. Істотними перевагами цієї методики є високий ступінь автоматизації оброблення супутникових знімків і використання даних дистанційного зондування землі, що перебувають у вільному доступі в мережі Інтернет. Користувачами такої вебслужби можуть бути державні контрольні структури, служби з боротьби з надзвичайними ситуаціями, поліція, лісова й муніципальні служби, екологічна служба, телерадіокомпанії та інші засоби масової інформації, а також населення, яке проживає поблизу територій, постраждалих від незаконного видобутку бурштину.

Ще одним напрацюванням у напрямку виявлення незаконних порушень за допомогою космічної зйомки, яке допомагає вирішити цю проблему, є використання мультиспектральних супутникових знімків високої роздільності Sentinel-2 (Filipovych et al., 2014; Ji, Zhang \& Wylie, 2009). Завдяки високій роздільній здатності (10, 20 м), геометричній точності (20 м без опорних точок та 5-10 м з їх використанням) та періоду знімання, такі дані незамінні у процесі моніторингу екологічно небезпечних явищ. Методика опрацювання даних, як і в попередніх знімках, розділена на декілька етапів:

- виконання підготовчих робіт, зокрема атмосферна корекція, приведення всіх каналів зображення до одного значення, вирізання досліджуваної області;

- побудова індексних та композитних зображень, вибір індексів та композитів, які найкраще підходять для ідентифікації порушених земель;

- визначення контурів ділянок;

- визначення площ порушених земель, оцінка їх точності.

Основним інструментом, в якому обробляли знімки, є програма SNAP 4.0 (англ. Sentinel Application Platform). До основних переваг цього програмного продукту належить наявність готових модулів і скриптів, розроблених спеціально для роботи 3 мультиспектральними та радіолокаційними знімками, отриманими супутниками Sentinel-1 та Sentinel-2, що істотно пришвидшує процес їх оброблення.

Для проведення досліджень насамперед потрібно підготувати вихідні дані. На цьому етапі виконували атмосферну корекцію зображень з використанням Senti$n e l-2$, який інтегровано в програмне середовище SNAP. Результатом роботи зазначеного вище модуля є зображення 3 рівнем оброблення L2A. Для виконання подальших робіт важливим $є$ приведення роздільності всіх каналів зображення до одного значення. Зважаючи на розміри знімків $(280 \times 280$ км $)$ та складність опрацювання даних таких розмірів, виконують вирізання досліджуваної області. Після виконання підготовчих робіт здійснюють побудову індексних та композитних зображень. Враховуючи інтерпретаційну перевагу зображень за вегетаційними індексами PVI, AVI, WDVI, MSVI1, OSAVI, GEMI, ARVI, SARVI (Bardysh \& Burshtynska, 2014), у подальших дослідженнях аналізували продукти, отримані на основі зазначених вище індексів.

Порівнявши індексні зображення, встановлено, що найкраще для ідентифікації порушених унаслідок видобування бурштину земель підходять гріди, побудовані за індексом GEMI (рис. 2,a).

Червоний колір відповідає відкритим грунтам та водним об'єктам. Враховуючи надмірну зволоженість грунту на ділянках з видобуванням бурштину у зв'язку з використанням гідропомпових агрегатів, окрім вегета- 
ційних індексів, було проаналізовано і водні індекси: NDWI, NDWI2, MNDWI, NDPI (Ji, Zhang \& Wylie, 2009). Найкращі результати вдалося отримати за індексом NDWI2 (див. рис. 2,б).

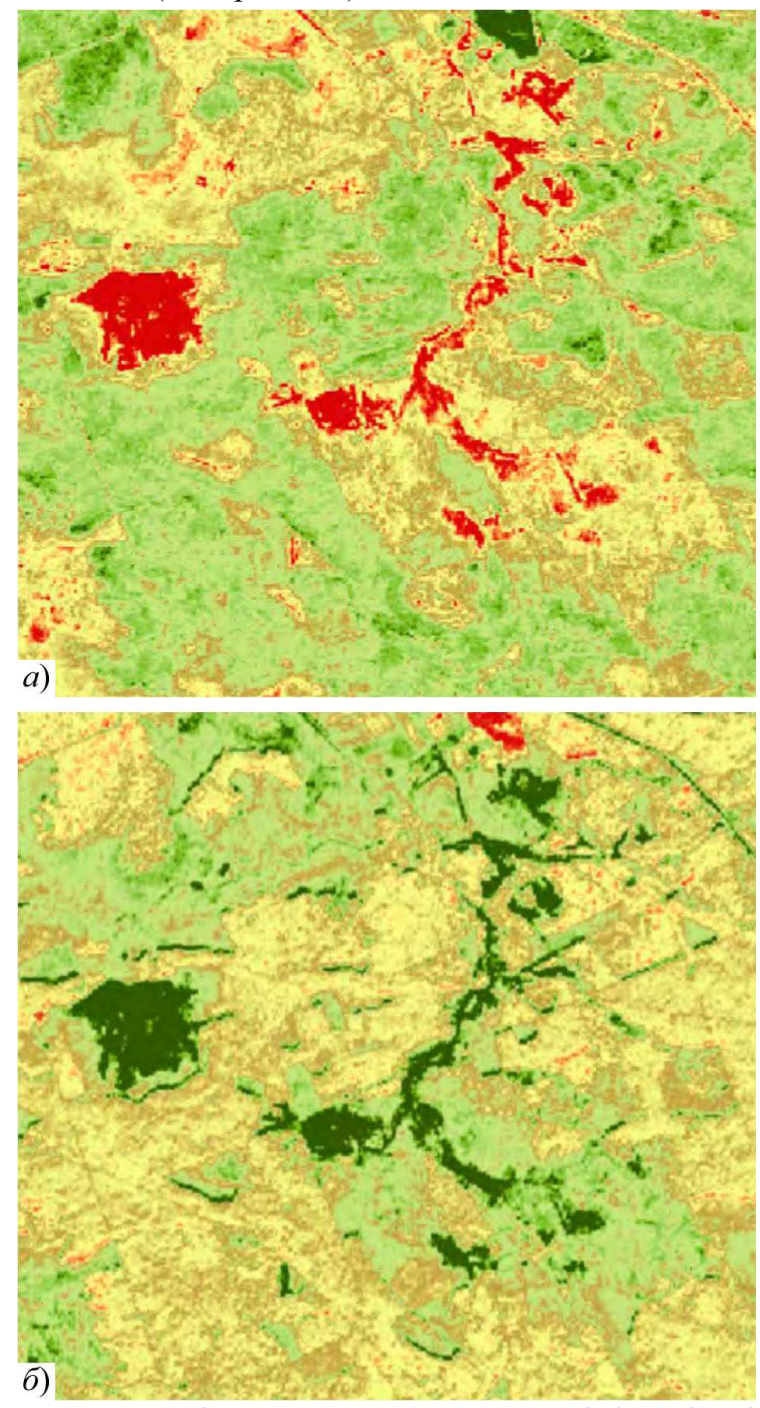

Рис. 2. Фрагмент індексного зображення (Yanchuk, Prokopchuk \& Trokhymets, 2017): a) за індексом GEMI; б) за індексом NDWI2

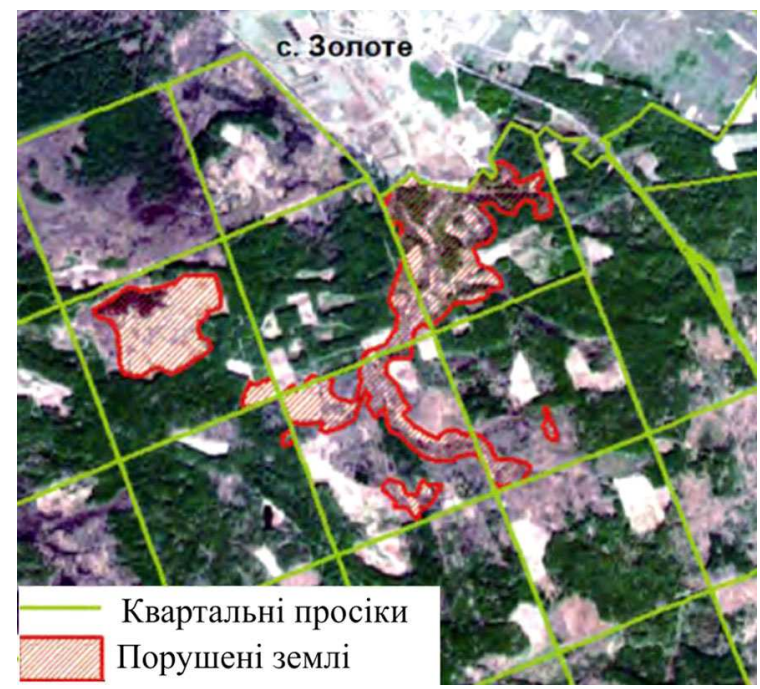

Рис. 3. Порушені землі, виявлені під час аналізу знімків Sentinel-2 (Yanchuk, Prokopchuk \& Trokhymets, 2017)

Зеленим кольором позначено ділянки 3 більшим вмістом води у грунті, червоним - сухіші ділянки. За- уважимо, що ідентифікація порушених земель на основі зображень, побудованих за вказаним вище індексом, актуальна тільки на заліснених територіях (рис. 3).

Для підвищення точності оконтурювання та виявлення порушень на вкритих лісовою рослинністю лісових ділянок, зокрема хвойних порід, на етапі побудови масок доцільно використовувати як індексні, так і композитні зображення. Площа порушених земель на досліджуваній території становить 99,1 га. Розходження між площами, визначеними зі знімків Sentinel-2 та ортофотопланом місцевості масштабу 1:5000, становлять у середньому $2 \%$. Наведену методику ідентифікації порушених земель можна покращити з використанням результатів тематичного оброблення радіолокаційних супутникових знімків.

Висновки. Використання дистанційного зондування землі на вкритих лісовою рослинністю лісових ділянках, які постраждали внаслідок незаконного видобутку бурштину, $\epsilon$ найефективнішим засобом моніторингу діяльності 3 використанням супутникових знімків середнього та високого просторового розрізнення. Застосування космічних даних на регіональному рівні дає змогу виявити ділянки незаконного видобутку та здійснити контроль за станом навколишнього середовища. Натомість знімки локального рівня дають змогу детально вивчити порушені площі, здійснити оцінку екологічних та економічних збитків, прослідкувати дотримання контролю за станом поверхневих вод, рекультивації порушених ландшафтів та ін.

\section{Перелік використаних джерел}

Baranova, V. O. (2015). Aktualni problemy zakonotvorchosti u sferi lehalizatsii vydobutku burshtynu. Zbirnyk materialiv Vseukrainskoi naukovo-praktychnoi konferentsii, (pp. 130-136). [In Ukrainian].

Bardysh, B., \& Burshtynska, Kh. (2014). Use of vegetation indexes to identify terrestrial objects. Contemporary achievements in geodetic science and production, 2(28), 82-88. [In Ukrainian].

Filipovych, V. Ye. (2015). Operational control over the distribution of illegal amber extraction and assessment of damage caused to the state by materials of multizone space shooting. Environmental safety and nature management, 4, 91-97. [In Ukrainian].

Filipovych, V. Ye. (2015). Satellite monitoring of the areas of illegal amber mining. Ukrainian Journal of Earth Remote Sensing, 4-7. [In Ukrainian].

Filipovych, V. Ye., Krylova, H. B., \& Lubskyi, M. S. (2015). Metodyka poshuku ta lokalizatsii dilianok nezakonnoho vydobutku burshtynu za materialamy bahatozonalnoi kosmichnoi ziomky. Suchasni informatsiini tekhnolohii upravlinnia ekolohichnoiu bezpeko$i u$, pryrodokorystuvanniam, zakhodamy $v$ nadzvychainykh sytuatsiiakh: Zbirnyk naukovykh prats Mizhnarodnoi naukovopraktychnoi konferentsii, (pp. 189-198). [In Ukrainian].

Hnatushenko, V. V., Hnatushenko, Vik. V., Mozgovyi, D. K., \& Vasyliev, V. V. (2016). Satellite technology of the forest fires effects monitoring. Bulletin of the National Mining University, 70-76.

Ji, L., Zhang, L., \& Wylie, B. (2009). Analysis of dynamic thresholds for the normalized difference water index Photogramm. Eng. Remote Sens, 75(11), 1307-1317.

Sakti, A., \& Tsuyuki, S. (2015). Spectral Mixture Analysis of Landsat Imagery for Land Cover Change Study of Highly Degraded Peatland in Indonesia, (pp. 495-501).

Yanchuk, R., Prokopchuk, A., \& Trokhymets, S. (2017). Identification and determination of areas affected by land amber extraction based on Sentinel-2 multi-valued satellite images. Contemporary achievements in geodetic science and production, 1(33), 120-124. [In Ukrainian].

Zhang, H., Lin, H., \& Li, Y. (2015). Impacts of feature normalization on optical and SAR data fusion for land use/land cover classification. IEEE Geosci. Remote Sensing, 1061-1065. 


\section{DETECTION OF CIRCUIT FOCUS OF AMBER MINERALS} ON THE TERRITORY OF FORESTS OF UKRAINE

In the structure of the national economy there are sectors whose functioning is based on the use of natural resources and natural conditions. The rational use of natural goods is at the heart of sustainable development and is becoming very necessary in our time. In the aspect of ensuring the transition of society to the principles of sustainable development, the important task is to assess the risks of loss, destruction of ecosystems under the influence of anthropogenic impact, is closely linked to their reliability. Therefore, there is a need to analyze the state of use of technologies of remote sensing of the land in the forest areas of Ukraine, where mining is carried out, on the example of amber. The article is devoted to the problem of illegal mining of amber and the analysis of the damage caused to forests in the course of such activities using aviation intelligence and satellite imagery of various series. Attention is focused on the scale of anthropogenic pressure in the forest areas of Ukraine as a result of amber mining. We have analyzed the achievements of domestic institutions of satellite research of disturbed lands and considered the problems and prospects of using satellite data to solve problems associated with illegal mining of amber. We have also studied the possibilities of identifying amber mining sites on the territory of forestry enterprises using Landsat, WorldView and Sentinel images. Highly informative observations from artificial satellites of the Earth enable quick and objective assessing of the areas affected by amber mining and estimating losses of forest resources, as well as investigating changes that occurred in forest plantations, and identifying new mining sites for subsequent control of their legality. This method of identifying foci of illegal mining allows us to take timely measures for the rational use of forest resources and to prevent damage caused by the uncontrolled seizure of forests and the further mining of amber minerals.

Keywords: amber mining; disturbed lands; multi-zone satellite images; forests; index and composite images. 